to judge the validity of his hypotheses, but if proved correct they will greatly clarify the basis of the physical treatment of psychiatric disorders. His routine work in the hospital displayed the same thorough probing attitude toward every clinical problem that came his way.

He was a quiet man, unobtrusively kind, and his politeness and reserve largely concealed his considerable erudition. During his years at Stone House Hospital he carried a heavy burden of medical administrative responsibility and worked ceaselessly to improve the psychiatric facilities for the people of Gravesend. His efforts met with much frustration and delay, which he accepted with characteristic patience and wry humour. It is intended that the Day Hospital presently to be opened at Gravesend should be named after him, thus providing recognition of his long, steadfast service, the value of which was obscured by his own intense dislike of self-advertisement. In his death the hospital has lost a leading figure and a good and wise friend.

John (Jack) had two longstanding recreational pursuits, water sports and flying. Throughout his life he swam enthusiastically, had played polo, sailed, windsurfed, and in recent years practised surfing on a Malibu board whenever he visited Cornwall, a favourite holiday haunt since boyhood. Having learnt to fly while stationed in Egypt, he continued this interest, and, combining the two, built and flew an amphibious aeroplane, the hull of which was constructed in his own sitting-room. A member of the National Trust and other conservationist organisations, he had a love of quiet places and received great pleasure in animal and bird watching, particularly in the coastal regions. He leaves a wife and two stepdaughters, and many friends who will all miss his calm, loving kindness and his sense of humour and fun. There will be a memorial service (see below).-JCS.

\section{T BARRY}

\section{MD, FFARCS, DA}

Dr C T Barry, formerly consultant anaesthetist at the Western General Hospital, Edinburgh, died suddenly on 7 July. He was 69 .

Claude Thomas Barry was born on 22 November 1909 at Cork, where his father.was professor of physiology at Queen's College. The family moved to France, and in 1928 he became a medical student in Paris. He qualified in 1935 and was awarded a bronze medal for his thesis on the heredity of morbid characters acquired by man, inspired by one of his teachers, Professor Turpin. He came to Edinburgh, qualified with the Scottish triple qualification in 1937, and went to work in general practice in Enfield. At the outbreak of war he joined the RAMC and spent some time as an anaesthetist in India. On demobilisation he became a registrar in anaesthetics at the Postgraduate Medical School, Hammersmith, taking the diploma in anaesthetics in 1946. In 1948 he returned to Edinburgh, soon taking charge of the anaesthetic service at the Western General Hospital and presiding over the slow expansion of his department of two doctors to one now employing 11. He became FFARCS in 1953.

He was a kind and careful doctor, conscientious in the care of his patients. He read widely and was interested in clinical research, publishing his last paper on intravenous induction agents shortly before his retirement in 1974. As a teacher he was well respected, insisting that his protégés were as scrupulous as he in the performance of their duties. He had a particularly active retirement, both medically and physically, acting as a valued locum in his old department (he was indeed so employed this summer) and abroad. $\mathrm{He}$ continued to pursue his hobbies of photography, fishing, swimming, and climbing, a which latter activity he was wont to shame younger colleagues. He will be greatly missed, but we can take comfort in that he died happily admiring the view from the top of one of his beloved Scottish mountains. He is survived by three sons (one a trainee in his old department) and two daughters.-KBS.

\section{G KAY \\ MB, CHB, DIH}

Dr David Kay, a senior medical adviser with the Employment Medical Advisory Service, died on 14 June while on holiday in France. He was 52 .

David Griffiths Kay was born at Cambuslang, near Glasgow, on 1 February 1927, and after

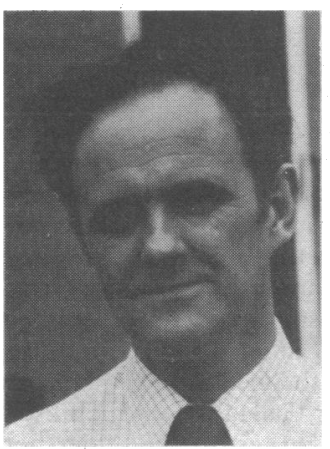
studying at local schools and at $S$ Mungo College graduated in medicine from Glasgow University in 1949. After early postgraduate training at Hairmyres Hospital East Kilbride, he joined the RAF for a two-year spell in 1950 . He served with distinction and was a well-respected officer, known for his sense of duty. He then moved to Trimdon in County Durham in 1952 and spent the nex four and a half years in general medical practice. The National Coal Board persuaded him to join them as their area medical officer in Durham in 1956, a post he held until 1968, when promotion and the bustling activity of the pits in South Yorkshire attracted him to work as senior medical officer in this region. In 1971 he joined the Employment Medical Advisory Service, which he served until his death.

David believed in serving his profession diligently and with the highest standards, and was always keen to keep himself abreast of developments and modern innovations. $\mathrm{He}$ was keenly interested in occupational health and after gaining a diploma in industrial health developed a special interest in the problems encountered by the miners, which later resulted in the publication of his paper on beat knees. In spite of his failing health (he had two coronaries) he continued to battle on and take an active interest in his work. He was often to be seen in the scientific meeting arranged by the Rotherham Division of the BMA and the meetings of the Society of Occupational Medicine, where he frequently read papers on his interested topics and continued to research in his chosen specialty till the very end. A shy and unassuming person, he was noted among his friends and colleagues for his undemonstrative nature, gentle manners, and unfailing courtesy. His cultivated tastes, extreme kindness, and typical English stoicism, tinged with subtle Scottish humour, always endeared him to those who knew him closely. Underneath his easy manner and humble personality he had a great reservoir of energy and hard work. He had made a valuable contribution to occupational medicine and ever since 1974 had been the spearhead of EMAS in Sheffield, where he is greatly missed. Dr Kay is survived by his wife Lillian, who was a constant source of encouragement to him, and two sons, who were his joy and pride. One of them, James, has followed his father into his profession.MHH.

\section{EVA McKINNA} MB, BS

Dr Eva McKinna, who was formerly in general practice at West Bridgford, Nottinghamshire, died on 30 August. She was 80 .

Eva McKinna, daughter of James and Janet Young, was born at Manchester on 30 June 1899 and educated at Skinner's School for Girls. She qualified in 1922 at the London Royal Free Hospital School of Medicine for Women and joined the house staff of Notting ham General Hospital, where she met her husband, Dr Henry Drummond McKinna. They first lived at Parson's Green, London, and then in 1931 moved to West Bridgford, Nottinghamshire, where they were in in dependent practices. Her husband died suddenly in 1945 and she took on his considerable practice as well as her own and continued with two partners until her retirement in 1963. She was loved by patients of all ages, who remember her for her devotion and kindness to individual patients, a kindness that often went beyond the bounds of medical care.

After her retirement she remained in the area and kept up links with large numbers of friends and a close association with the Friary United Reform Church. She remained an active member of the Medical Women's Federation, where her wisdom and encouragement were invaluable to her younger colleagues. Her wide interests included reading, and she was a director of the Bromley House Library and supported the National Trust in many aspects of its work. She enjoyed her years of retirement to the full, travelled widely, and drew the deepest pleasure from her contacts with her family and grandchildren-in London and in Canada. She died in London after a brief illness, and will be sadly missed by he many friends, who owe her a great deal. She is survived by her two sons, who are both doctors.-TMP.

A memorial service for the late $\operatorname{Dr} J P$ Crawford, whose obituary is printed on $\mathrm{p} 741$ will be held in the chapel at Stone House Hospital, Dartford, Kent, on Friday 28 September, at $3 \mathrm{pm}$.

Mr E J Greenwood. In the obituary published on 8 September (p 621) Mrs Greenwood was inadvertently referred to as Helen, whereas she has always been known as Dorothy. We apologise for our error. 